\title{
The Pluralisation of Living Arrangements - A Continuous Trend?
}

\author{
Michael Wagner, Isabel Valdés Cifuentes
}

\begin{abstract}
This paper investigates to what extent a pluralisation of living arrangements can be observed in Germany up to the present day - both on the household level as well as the individual level. The analyses are based on data from the microcensus and the German General Social Survey (ALLBUS) from the last decades.

On the household level, eight different living arrangements are distinguished depending on the marital status and the number of generations living in the household. The results show that pluralisation mainly occurred between 1972 and 1996. In contrast, the diversity of living arrangements in West Germany has remained unchanged during the last 20 years, and it even slightly decreased in East Germany. A different picture emerges when separately looking at one-generation and twogeneration households. Living arrangements with children have also diversified in recent years, which is mainly the result of less married couples with children.

On the individual level, the classification of living arrangements was extended by the characteristic gender-specific division of labour, since the changed role of women is seen as the crucial factor for the changes in the familial sector. The results indicate a continuous pluralisation of living arrangements. This pluralisation of the familial sector is mainly caused by the male breadwinner model losing importance. This trend is more pronounced in East Germany than in West Germany.

A cohort analysis reveals a bimodal distribution of diversity on the age-axis: entropy is highest around the ages of 30 and 60, since living arrangements often change at these points. Individuals often marry around the age of 30 , and the transition to an "empty nest" mostly occurs around the age of 60 . The cohort analysis for different age groups shows that the diversity of living arrangements is generally higher amongst younger cohorts than amongst older cohorts.
\end{abstract}

Keywords: Pluralisation · Living arrangements · Household · Family · Entropy 


\section{Problem}

"A great diversity of animals and plants is an important condition for an effective ecosystem and a crucial resource for human life" (Statistisches Bundesamt 2011: 337; translated by CPoS). Even if the effect of biodiversity on the stability of the ecosystem is contested, terms such as "species extinction" or "protection of species" express that the preservation of "diversity" is connected to positive outcomes. Also in family sociology diversity is a prominent concept. To be more precise, it is the diversity of living arrangements that has been discussed in Germany since the 1980s. Family sociologists claimed a pluralisation of living arrangements, i.e. an increasing diversity over time (first Lüscher 1985; cf. also Nave-Herz 1988). Whereas an ecological diversity is generally desired, the pluralisation of living arrangements is evaluated sceptically by some and positively by other family sociologists. Some fear that traditional living arrangements, especially marriage and family, may disappear, others emphasize the increased number of options as new living arrangements have been established. But this diversity of living arrangements is not only constituted by new living arrangements such as cohabitating unmarried couples but also by divorces, widowhoods, and childlessness.

The pluralisation of living arrangements in Germany has been the subject of many studies (Brüder/ 2004; Diewald/Wehner 1996; Dorbritz 2010; Engstler/TeschRömer 2010; Franzmann/Wagner 1999; Höhn/Dorbritz 1995; Huinink/Wagner 1998; Marbach 2003; Strohmeier 1993; Wagner 2008; Wagner/Franzmann 2000). Most of these studies merely find a small increase in diversity, which is attributed to the loss of dominance of the "normal family" that was common in the 1950s and 1960s, whereas households without children - especially single and cohabiting households - gained in importance (Höhn/Dorbritz 1995; Klein 1999; Strohmeier 1993; Wagner 2008).

The aim of this research is to analyse the changes of living arrangements based on data from official statistics (microcensus) and the German General Social Survey (ALLBUS). It contrasts previous studies in a number of ways: first, existing studies (cf. Wagner 2008) are updated to include later trends, so that developments of the last 40 years can be described by the microcensus and developments of the last 30 years by the ALLBUS. Second, one-generation and two-generation households are investigated separately, which allows describing the development of diversity of both the familial and the non-familial sector. Third, this paper analyses how the diversity of living arrangements varies between cohorts and within cohorts between different age groups for East and West Germany separately (cf. Brüderl/Klein 2003; Diewald/Wehner 1996; Wagner et al. 2001).

\section{Theoretical considerations and current state of research}

Despite numerous studies on the subject, the pluralisation of living arrangements is insufficiently explained. There are many reasons for this situation. First, an increasing diversity of living arrangements can take both a distributive and a structural 
form. In the former case, the population is distributed more equally across existing living arrangements, in the latter, new living arrangements become institutionalised and therefore the number of different types of living arrangements increases (Franzmann/Wagner 1999; Peet 1974). However, a structural increase of diversity is difficult to measure, since it is difficult to determine unambiguously under which circumstances and when a new type of living arrangement can be defined as established. Therefore, most research on the pluralisation of living arrangements focuses on distributive diversity, i.e. the distribution of the population over different living arrangements.

Second, the diversity of living arrangements is a macro-structural or aggregate characteristic resulting from different micro-level processes. With regard to a particular period of time, it would be necessary to explain separately - and quasi-simultaneously - for every living arrangement why a certain share of the population chooses or changes it. Such a complex theoretical concept faces multiple demands. A change in the living arrangement can happen in two different ways: a person decides on a different living arrangement, or a person participating in the living arrangement decides on a change. For example, an individual living alone can decide to cohabit. Alternatively, an individual who is cohabiting and whose partner decides to terminate the relationship and to move out may change the current living arrangement due to this separation. Considering the consequences of widowhood or the moving out of the last child from the parental home, it becomes obvious that only some changes of living arrangements can be attributed to a person's choice. Even a universal theory of living arrangement choices could not cover all the social conditions that are responsible for the diversity of living arrangements in a society.

Third, the changes in the diversity of living arrangements need to be explained. This also applies to the question which social conditions lead to the emergence of new living arrangements or the decline of traditional living arrangements within a society. This does not only involve the "emergence" of new living arrangements but also the mechanisms of its social diffusion. More generally, one could say that the distribution of living arrangements at a certain point in time are always the result of a complex process, which is not only largely unknown, but whose form and parameters themselves can change. Thus, it is not necessarily always the same conditions and factors that are responsible for the diffusion of living arrangements or the distribution of the population over a number of given living arrangements.

Fourth, it needs to be considered that the diversity of living arrangements is not constituted by individuals in a certain phase of life. It is rather determined by living arrangements and changes between different living arrangements that happen over the whole life course. Thus, the significance of new living arrangements such as cohabitation - which mostly occur in the third and fourth decade of life and have diminished or removed the dominance of marriage in this age span - as a determinant of the pluralisation of living arrangements is put into perspective, since, at the same time, marriage may have gained in importance for older age groups. 


\subsection{Two typical theoretical approaches}

Following, we delineate two typical explanations for the diversity of living arrangements, two theories explaining the spread of unmarried or cohabiting partnerships. These belong to the "newer" living arrangements, which have become very widespread. The first approach builds on the theory of social differentiation, the second on action theory. To put it simply, the theory of social differentiation is a macro-theory that needs to be micro-sociologically substantiated, whereas action theory is a micro-theory that needs macro-sociological complements if it wants to explain the spread of living arrangements. For example, it makes assumptions on how situations crucial for deciding on a living arrangement have altered in the course of social change. Both approaches only partly explain the diversity of living arrangements.

The theory of social differentiation (cf. Schimank 2000) assumes that modern societies can be divided into subsystems with different functions. The family is seen as a social subsystem segregated into numerous single families as well, although this approach has been criticised. "Functions" can be understood as the aggregated output or benefits that families provide for other social systems (Kaufmann 1995: 35; Nave-Herz 1999). These benefits include socialisation and reproduction. NaveHerz (1999: 44) mentions the creation and preservation of human capital, which means both the reproduction and the psychological and physical regeneration. The diversity of living arrangements can be understood as the result of a differentiation of the social subsystem family.

This differentiation can be explained by two different causes (Schimank 2000). First, agents can cause differentiation via a "differentiation policy". For example, legislative amendments lead to a promotion of other living arrangements than marriage. These include the equalising legal status of unmarried and married couples, the improved legal situation of unmarried fathers and the altered rights of custody. These positive incentives make unmarried living arrangements more attractive.

A second explanation for the pluralisation is to view it as the result of an evolutionary process (Meyer 1993). Pluralisation is understood as the adaptation of a social system - e.g. the subsystem family - to changed environmental conditions. This adaptation is facilitated by an increasing complexity of the social system. Meyer (1993) defines this complexity by stating that the system "privateness" can be divided into three subsystems: the children-oriented type specialising in socialising children, the relationship-oriented type focusing on the relationship, and the individualistic type comprising singles and shared accommodations and thus individuals deliberately choosing autonomy and independence. The differentiation of the system family thus creates new behavioural expectations, i.e. norms, and individual orientations which characterise each subsystem.

The environment of the family also includes other social systems, for example the educational system or the employment market, but also cultural trends or political movements. Especially the changes in the educational system and the job market have led to higher qualifications, longer educational periods and increas- 
ing labour participation of women. ${ }^{1}$ This led to a decrease in rates of marriage and childbirth, which, under a constant propensity of forming relationships, promoted cohabitation and - especially in the student milieu - shared accommodation. These processes have also changed the beliefs about gender roles and questioned the traditional gender-specific division of labour in middle-class families (Amato et al. 2007; Beck 1983; Crouch 2004; Esping-Andersen 2009).

Similarly, Kaufmann (1995) assumes that the pluralisation of living arrangements is caused by a change in norms, by a culturally determined increase in options, which was initiated by the criticism of the "middle-class family" and the emancipation movement of the 1960s. These increased options include the uncoupling of sexuality and reproduction, love and marriage, marriage and parenthood, and of biological and social parenthood. This cultural liberalisation leads to a deinstitutionalisation of marriage and an institutionalisation of new living arrangements (Kaufmann 1988, 1995; Tyrell 1979, 1988; Amato et al. 2007).

The action-theoretical approach, in explaining the proliferation of unmarried relationships, criticises the differentiation theory for leaving the causes of differentiation unexplained (Hill/Kopp 1999: 15). It calls for a decision theory that consolidates macro-structural changes. Differentiation theorists are further criticised for not having a "stop rule" for the process of pluralisation (Hill/Kopp 1999: 17). Action theory believes that transitions between living arrangements should be modelled as decision-making situations that occur under certain social conditions. The transition of relationships, in which partners live in separate households, to an unmarried but cohabiting relationship is explained by a reduction in transaction costs, which is aspired to once the intensity of interaction between the partners has exceeded a critical threshold. The establishment of a cohabiting household allows a cost-saving division of labour, and the couple gains more time together (Hill/Kopp 1999: 25). Again, changes in the educational and the employment sector, especially regarding the situation of women, contribute to the diffusion of unmarried relationships. For women, marriage often - especially when it accompanies the family formation - implies taking on the role of a housewife, which involves high opportunity costs considering good employment chances.

These theoretical considerations and social trends do not allow predicting the diffusion of new living arrangements or changes in the diversity of living arrangements. It cannot be foreseen whether there will be more legal provisions equalising marriages and unmarried relationships (UMR) in the future; changes of the economic - especially fiscal - conditions, however, may lead to an increase of cohabitation and thus to a further pluralisation of living arrangements. This would also happen if the number of men and women with a university degree increases - a fairly realistic development (Statistisches Bundesamt 2011: 59). Considering that the percentage of female first-year students has remained more or less constant during the last decade (Statistisches Bundesamt 2011: 63) and that the rate of female labour force

1 Economic factors are also relevant: increasing wealth and changes in both employment and consumption. 
participation has only slightly increased (Statistisches Bundesamt 2011: 110), these developments are unlikely to lead to a significant increase in living arrangements with or without children - outside marriage.

\subsection{Current state of research on the diversity of living arrangements}

Starting with the structural diversity of living arrangements, literature agrees that unmarried relationships are a new type of living arrangement. One indicator for the institutionalisation of a living arrangement is its representation in current law. In West Germany, for example, unmarried cohabitation was legally recognised by abolishing the paragraph on procuration in 1974 and by defining cohabitation. More recently, the terms living arrangement and same-sex relationships were introduced into official statistics in 2005 (Heidenreich/Nöthen 2002; Nöthen 2005). Since other living arrangements were not simultaneously deinstitutionalised, the structural diversity of living arrangements has at least increased.

Empirical evidence regarding the distributive diversity of living arrangements is limited, because most studies only found a marginal increase in this diversity. Using data from official statistics (microcensus) and the German Population Policy Acceptance Study (PPAS), Dorbritz (2004) concludes that an ending of the "normal family" is not to be expected. He states, "The development of the last 30 years does not show an emergence of new living arrangements on a large scale, but rather a new distribution of the population over different well-known living arrangements, in which married couples with children are no longer dominant" (Dorbritz 2004: 341, translated by CPoS). Further, East and West Germany still differ, which can be seen in a slightly greater diversity of living arrangements in the new federal states of East Germany (Dorbritz 2004; Huinink/Wagner 1998; Marbach 2003).

Based on the microcensus, Lengerer (2011: 122-135) finds that the number of marriages is declining - stronger and faster in East Germany than in West Germany - a fact that cannot be compensated by an increase in unmarried relationships. This means that the number of people living without a partner has grown, i.e. a decline of partnerships living in a common household. However, marriage remains the most common living arrangement for people of all ages with the exception of the 16-to30-year olds. Lengerer's findings confirm earlier results of Höhn and Dorbritz from 1995 , who found a small growth of the non-family sector and a decline in marriages but still an overall percentage of married people of 75 percent in 1988. These results may not be surprising for the year 1988 and yet - considering recent studies - they indicate a continuing dominance of marriage among the various forms of living arrangements. Strohmeier (1993: 16) comes to a similar result; he finds a "polarised" family sector, since both unmarried relationships and people living alone have become more prevalent while the number of married couples has declined.

The attractiveness of "new" living arrangements differs between population groups: the diversity of living arrangements increases with the level of education and decreases with age (Lengerer 2011; Strohmeier 1993). Recently, however, older people as well increasingly prefer new living arrangements such as unmarried relationships (Diewald/Wehner 1996; Dorbritz 2004: 346; Dorbritz 2010; Engstler/ 
Tesch-Römer 2010; Meyer/Schulze 1983; Peuckert 2008; Zapf et al. 1987). Further, the diversity of living arrangements is greater in cities, since there is a stronger social pressure for traditional living arrangements in less urbanised regions (Diewald/ Wehner 1996: 135; Klein 2005: 187). The degree of religiousness also influences the choice of a living arrangement, because religious people rather hold traditional norms and values and thus prefer marriage (Dorbritz 2004; Holzem/Weber 2008; Huinink/Konietzka 2003).

Using the third wave of the German family survey, Brüderl and Klein (2003) and Brüderl (2004) focus on relationships and analyse living arrangements over the life course of 18-to-55-year olds. They find that the diversity of relationships has increased slightly and that it further increases with the size of the respondent's place of residence but not with the level of education. Especially the time spent living single and the number of times people change their living arrangement have increased.

Huinink and Wagner (1998) analyse the changing fractions as well as the development of different measures of heterogeneity of living arrangements, a study that was later replicated by Wagner and Franzmann (2000) and Wagner (2008). Microcensus data from 1972, 1996, and 2000 indicate that living arrangements have diversified slightly: single households increase while the share of married couples with children declines. The identified measures of heterogeneity reveal a significant increase in diversity in West Germany during the 1980s and, since then, a constant level of diversity in both East and West Germany. A more recent study by Engstler and Tesch-Römer (2010) confirms these results for older age groups.

Most research thus indicates a small and by no means dramatic pluralisation of living arrangements. Whether this is a continuous trend and whether these changes apply to all age groups in East and West Germany is analysed in this paper. First, though, the methods, the selection of variables, the approach of empirical analysis as well as some statistical measures of heterogeneity, which allow specifying the diversity of living arrangements, are introduced.

\section{Data and Methods}

\subsection{Measures of diversity}

There are a multitude of statistical measures of diversity (or heterogeneity) or qualitative variance (Peet 1974). This study uses the measure of entropy, which signals the uncertainty of finding a particular person in a certain category (Franzmann/Wagner 1999: 78-80; Wagner/Franzmann 2000: 156-158). This measure is especially appropriate for analysing the diversity of living arrangements, since it gives stronger 
weight to less widespread living arrangements by calculating the logarithm of their fractions for the analysis. ${ }^{2}$ If this value is zero, all people belong to one category and the uncertainty to find a person in another living arrangement is minimal. The measure reaches its maximum value when all individuals are spread approximately equally across the different categories; this is termed the greatest uncertainty possible. The equation for the unstandardised entropy $H$ according to Coulter (1989) is

$$
H=\sum_{i=1}^{K} p_{i} \log _{2} \frac{1}{p_{i}}
$$

where $H$ denotes entropy, $p$ fraction and $K$ the number of categories.

In order to compare values with a differing number of categories, a standardisation is suggested: the entropy is divided by the maximum value possible ${ }^{3}$ and thus lies between zero and one, where zero is the smallest possible diversity.

One problem with these measures is that they only take into account the relative proportions of living arrangements, irrespectively of a particular living arrangement. In other words, if a dominant category is replaced by another category, the diversity or heterogeneity measure will not change. Thus, it is necessary to consider the particular changes of relative proportions in addition to the measured values of entropy.

\subsection{Method of data collection}

The analysis of types of households in East and West Germany is conducted using the 2007 microcensus. The microcensus is the "only on-going statistic on households, families and living arrangements of the German population" (Lengerer et al. 2007: 187, translated by CPoS). While households describe the economic community of individuals, families are defined by the traditional concept of parenthood or marriage. Since 2005 , living arrangements are defined as social units within a household that account for the individual constellation of relationships. This includes unmarried and same-sex relationships, which were previously not recorded by the traditional concept of family (Lengerer et al. 2007: 188-190).

The population of the microcensus consists of all people entitled to live in Germany. For this study, only German citizens living in private accommodation are taken into consideration. In order to apply the analysis to the household level, variables were filtered for the reference person of the household leading to a number

2 Another measure of qualitative variance is the "index of diversity" providing the countervalue of the Herfindahl-Index (Lieberson 1969). It measures the probability that two respondents belong to two different categories and emphasises strongly populated living arrangements by squaring the fractions for analysis. The paper highlights points at which diversity and entropy strongly differ.

3 The maximum value of the unstandardised entropy is $\log _{2} \mathrm{~K}$. This value increases with the number of categories. 
of 215,503 households. ${ }^{4}$ The Scientific Use File (SUF) that is used is a "factuallyanonymised 70 percent-subsample of the households" of the original microcensus data 2007 (Statistisches Bundesamt 2010: 5). All data are weighted using the standard extrapolation factor EF952. Classification is conducted using criteria like marital status, parenthood, and number of generations in the household, which produces eight different categories. Analyses ${ }^{5}$ are conducted separately for East and West Germany, whereby the results from 2007 are compared to the years 1972 (West Germany only), 1996, and 2000, which are taken from Wagner (2008: 109). In order to be able to compare our study with data from previous years, we cannot classify the data using the concept of living arrangements that was introduced into the microcensus in 2005. Instead, the study is based on the reference person of the household. Therefore, the terms living arrangement and type of household are subsequently used synonymously.

The analysis of the development of living arrangements on the individual level is conducted using the cumulated ALLBUS from 1980-2008 complemented by the survey from 2010. The ALLBUS is a "Iong-term, multi-thematic series of surveys regarding attitudes, behaviours and social structures of the population in Germany" (GESIS 2010, translated by CPoS), which is conducted every two years and represents a cross section of the German population. Due to the long period of time covered by the ALLBUS and its potential of classifying living arrangements in fine details, these data are especially suitable for this analysis.

The population of the ALLBUS consisted of all West German citizens eligible to vote until 1990. Since 1991, it also includes East Germans as well as people of foreign nationalities. This paper takes into account the waves in 1980/82 (western Germany only), 1991/92, 1998/2000, 2004/06, and 2008/2010, and weights the data using the person transformation weight. ${ }^{6}$

We distinguish between 26 living arrangements by differentiating not only marital status and parenthood but also gender and gender-specific division of employment. The differentiation of gender and employment is conducted assuming that the changing role of women plays an important part in the changing distribution of living arrangements. The definition of living arrangements is again based on the household. Thus, people are classified as parents when their own or adopted children live in the same household; people whose children have already moved out are defined as being childless. Both people working part-time and full-time are de-

4 The corresponding variables of the SUF 2007 are EF31 (private households) and EF37 (reference person of the household).

5 Variables of the SUF 2007 used: EF33 (partner living in the household), EF663 (number of people in the household), EF669 (unmarried child in the household), EF721 (type of relationship), EF722 (Number of generations).

6

The most important variables of the cumulated ALLBUS (1980-2008): v722 (marital status), v568 (employment), v808 (employment of the married partner), v917 (employment of the partner), v1083 (relationship to the second person etc.), v1155 (household classification), for the years 1998/2000, 2004/06, and 2008/10: v1325 (person transformation weight East West), for the years 1991/92 and 1980/82: v1323 (person transformation weight). 
fined as in employment. The corresponding heterogeneity index is calculated using the equation above. ${ }^{7}$

This classification has one weakness: it is possible to classify people in the same living arrangement into different categories depending on which person of the household is interviewed. For example, a married, unemployed mother living with her unemployed husband and her adult child would be classified into the category "marriage, children, both unemployed". However, if her child is interviewed, it would be sorted into the category "Adult child, lives with parents, no child", although both people live in the same household.

The results based on the ALLBUS largely confirm the results based on the microcensus. As expected, the living arrangements that are difficult to capture in social scientific surveys - such as single person households - are underrepresented compared to official statistics, whereas living arrangements that are easily captured - such as marriage - are slightly overrepresented. However, apart from these slight deviations, the results are in agreement with each other, especially regarding the measures of heterogeneity. Thus, the results of the ALLBUS are representative (see Table A1 in the appendix).

\section{$4 \quad$ The Pluralisation of Living arrangements: Empirical Results}

\subsection{Household-level analysis}

As described above, the households included in the microcensus are classified by the number of generations living in them. The measures of heterogeneity highlight a clear difference between East and West Germany (see Table 1). In West Germany, entropy increased between 1972 and 1996 and has remained fairly constant afterwards. ${ }^{8}$ In East Germany, in contrast, the originally higher entropy has been decreasing steadily, even in recent years. Thus, the diversity in East and West Germany is slowly converging.

Regarding the distribution of households over different living arrangements, a shift towards one-generation-households is noticeable both in East and West Germany, but especially in East Germany. Whereas the distribution between one- and two-generation households was roughly equal in 1972, nowadays approximately 70 percent of all households accommodate only one generation; only 30 percent of all households include children. The largest group of households without children are one-person households, which make up 40 percent of all households. This change occurred between 1972 and 1996 in West Germany, whereas it was still increasing after 2000 in East Germany. The percentage of married couples without

7 This analysis is a replication of earlier studies by Wagner (2008), whereby the data for the earlier years $(1980 / 82,1991 / 92,1998 / 2000,2004 / 06)$ are re-calculated due to small deviations from earlier results.

8 In contrast, the diversity index remains constant due to the changing dominant groups. 
Tab. 1: Types of households according to the microcensus in 1972, 1996, 2000, and 2007 (households in \%, measure of diversity)

\begin{tabular}{lrrrrrrr}
\hline & \multicolumn{3}{c}{ West Germany } & \multicolumn{3}{c}{ East Germany } \\
Type of household & 1972 & 1996 & 2000 & 2007 & 1996 & 2000 & 2007 \\
\hline A: One-generation households & 50.1 & 64.9 & 66.0 & 68.9 & 60.1 & 64.4 & 71.5 \\
- Married couples without children (1) & 23.1 & 24.5 & 25.0 & 25.2 & 25.6 & 25.8 & 25.6 \\
- UMRs ' without children (2) & 0.5 & 3.7 & 4.0 & 4.7 & 3.3 & 3.8 & 4.1 \\
- Single-person households (3) & 26.4 & 36.7 & 37.0 & 39.0 & 31.1 & 34.8 & 41.8 \\
B: Two-generation households & 46.5 & 34.1 & 33.2 & 30.6 & 39.0 & 34.7 & 28.1 \\
- Married couples with children (4) & 39.3 & 27.1 & 25.9 & 22.2 & 28.6 & 24.2 & 16.5 \\
- UMRs with children (5) & 0.1 & 0.9 & 0.8 & 1.6 & 3.3 & 2.2 & 3.5 \\
- Single parents (6) & 5.5 & 5.1 & 5.6 & 6.1 & 6.1 & 7.3 & 7.4 \\
- Households with married children (7) & 1.6 & 1.0 & 0.9 & 0.7 & 1.0 & 1.0 & 0.7 \\
C: Three- and more-generation households (8) & 3.4 & 1.0 & 0.8 & 0.6 & 0.9 & 0.8 & 0.5 \\
Total (A +B + C) & 100 & 100 & 100 & 100 & 100 & 100 & 100 \\
Measure of diversity & & & & & & & \\
- Entropy. unstandardised (max =3.00) & 2.06 & 2.13 & 2.13 & 2.15 & 2.24 & 2.23 & 2.18 \\
- Entropy. standardised & 0.69 & 0.71 & 0.71 & 0.72 & 0.75 & 0.74 & 0.73 \\
\hline
\end{tabular}

Household types (1) to (8) are used to calculate measures of diversity.

${ }^{1} \mathrm{UMR}=$ unmarried couple

Source: Engstler (1998: 49), Engstler/Menning (2003: 216), Wagner (2008: 109), and own calculations

children has remained fairly constant. Thus, single-person households and - on a much lower level - unmarried couples (UMR) without children are almost solely responsible for the increase in one-generation households. Households with children have lost their significance, especially married couples with children, whereas the percentage of unmarried relationships with children and single parents has slightly increased. Especially in East Germany, only 17 percent of households consist of this type of family, while the percentage of unmarried parents is comparatively high (4 percent).

Since the changes of one- and two-generation households are markedly different - which may in sum be the reason for entropy measures remaining fairly constant - it is worth looking at both sectors separately (see Table 2). The diversity of West German one-generation households increased between 1972 and 1996 and has remained fairly constant since then. In East Germany, their diversity has barely changed, apart from a slight decrease between 2000 and 2007. Due to the decline of childless marriages, the distribution of living arrangements has shifted between 1972 and 1996 in West Germany, whereas the percentage of married couples without children has declined and the percentage of one-person households have increased in recent years in East Germany.

However, within the familial sector, diversity has also increased in recent years. This pluralisation becomes obvious in East Germany, where entropy rose by 0.2 
Tab. 2: One-/Two-generation households in 1972, 1996, 2000, and 2007 (households in \%, measure of diversity)

\begin{tabular}{lrrrrrrr}
\hline & \multicolumn{3}{c}{ West Germany } & \multicolumn{3}{c}{ East Germany } \\
Type of household & 1972 & 1996 & 2000 & 2007 & 1996 & 2000 & 2007 \\
\hline One-generation households & 100 & 100 & 100 & 100 & 100 & 100 & 100 \\
- Married couples without children (1) & 46.1 & 37.8 & 37.9 & 36.6 & 42.6 & 40.1 & 35.8 \\
- UMRs ${ }^{1}$ without children (2) & 1.0 & 5.7 & 6.1 & 6.8 & 5.5 & 5.9 & 5.7 \\
- Single-person households (3) & 52.7 & 56.5 & 56.1 & 56.6 & 51.7 & 54.0 & 58.5 \\
Measure of diversity & & & & & & & \\
- Entropy. unstandardised (max =1.58) & 1.07 & 1.23 & 1.24 & 1.26 & 1.25 & 1.25 & 1.22 \\
- Entropy. standardised & 0.64 & 0.78 & 0.79 & 0.79 & 0.79 & 0.79 & 0.77 \\
\hline Two-generation households & 100 & 100 & 100 & 100 & 100 & 100 & 100 \\
- Married couples with children (4) & 84.5 & 79.5 & 78.0 & 72.5 & 73.3 & 69.7 & 58.7 \\
- UMR with children (5) & 0.2 & 2.6 & 2.4 & 5.2 & 8.5 & 6.3 & 12.5 \\
- Single parents (6) & 11.8 & 15.0 & 16.9 & 19.9 & 15.6 & 21.0 & 26.3 \\
- Households with married children (7) & 3.4 & 2.9 & 2.7 & 2.3 & 2.6 & 2.9 & 2.5 \\
& & & & & & & \\
Measure of diversity & & & & & & & \\
- Entropy. unstandardised (max = 2.00) & 0.75 & 0.96 & 0.98 & 1.14 & 1.19 & 1.24 & 1.45 \\
- Entropy. standardised & 0.38 & 0.48 & 0.49 & 0.57 & 0.59 & 0.62 & 0.73 \\
\hline
\end{tabular}

Source: see Table 1, own calculations

points between 2000 and 2007. This is due to a loss of importance of married families, a small increase in unmarried relationships with children and an increase in importance of single parents. Comparing the absolute values of the standardised entropy, it becomes obvious though that the diversity among households with children is lower than among households without children. Two-generation households can mainly be found among married couples, whereas especially two different living arrangements - single-person households and marriages - can be found among households without children.

\subsection{Individual-level analysis}

The ALLBUS data and, more explicitly, the waves in 1980/82 (West Germany only), 1991/92, 1998/2000, 2004/06, and 2008/10 are used for individual-level analysis. Table 3 illustrates the changes of the percentages of different living arrangements as 
well as the measures of diversity. Entropy is slightly higher in East Germany than in West Germany and increases over time in both parts of the country. ${ }^{9}$

Investigating the distribution of individuals over different living arrangements, it is observable that the diffusion of the traditional "normal family" - marriage, children, only the man employed - has decreased considerably. The percentage of respondents living in a "normal family" declined from 27 percent in 1980/82 to 12 percent in 2008/10 in West Germany, in East Germany it declined from a low 12 percent in 1991/92 to only 4 percent. It is only the third largest category in West Germany, in East Germany it ranks eighth. Thus, the traditional model of marriage with a male breadwinner is now outdated in West Germany as well.

However, despite marriage continuously losing importance, more than half of the (adult) German citizens are still living together as married couples (58 percent in West Germany, 54 percent in East Germany). The majority are couples not in work that can mostly be classified as pensioners. Simultaneously, a new form of relationship has spread, namely unmarried relationships, which have grown from 1 percent in 1980/82 to 7 percent in 2008/10 in West Germany. In East Germany, 11 percent are living in an unmarried relationship. However, the largest increase can be observed for single-person households, which have grown in both East and West Germany since the 1990s. In 2008/10, more than 20 percent of the population lived on their own, many of them older, presumably mostly widowed women.

Two further changes have occurred regarding the classification criteria parenthood and division of labour: in 1980/82, every second person lived together with a child in West Germany. This has declined to about every third person in West Germany, and only every fourth person in East Germany (27 percent). In both parts of the country, a decreasing number of people is living in arrangements with a traditional division of labour, i.e. relationships with or without children, where only the man is employed (living arrangement no. 1, 5, 9, and 13 in Table 3). In East Germany, they make up only 9 percent, in West Germany 17 percent of the population in 2008/10. In 1991/92, they still made up 18 percent (East) and 29 percent (West), respectively. However, living arrangements in which both partners are employed have increased only slightly in West Germany - similarly to living arrangements where the woman is the sole breadwinner - they have even partly decreased in East Germany.

The association between parenthood and marriage has weakened, but still exists in West Germany, since nearly all people who live with children are married. In $1980 / 82,48$ percent of the respondents were living with children (living arrangements 5-8, 13-16, and 18-21 in Table 3) and 91 percent of these were married. In 2008/10, 34 percent of the respondents were living with children and 81 percent of these were married. In East Germany, only 27 percent of the respondents were

9 The measure of diversity barely changes over time, and has been stagnating since 1998/2000. This is probably due to the detailed classification used here, which leads to very few groups being strongly populated. As explained above, changes in these groups are weighted heavily when calculating the measure of diversity. 


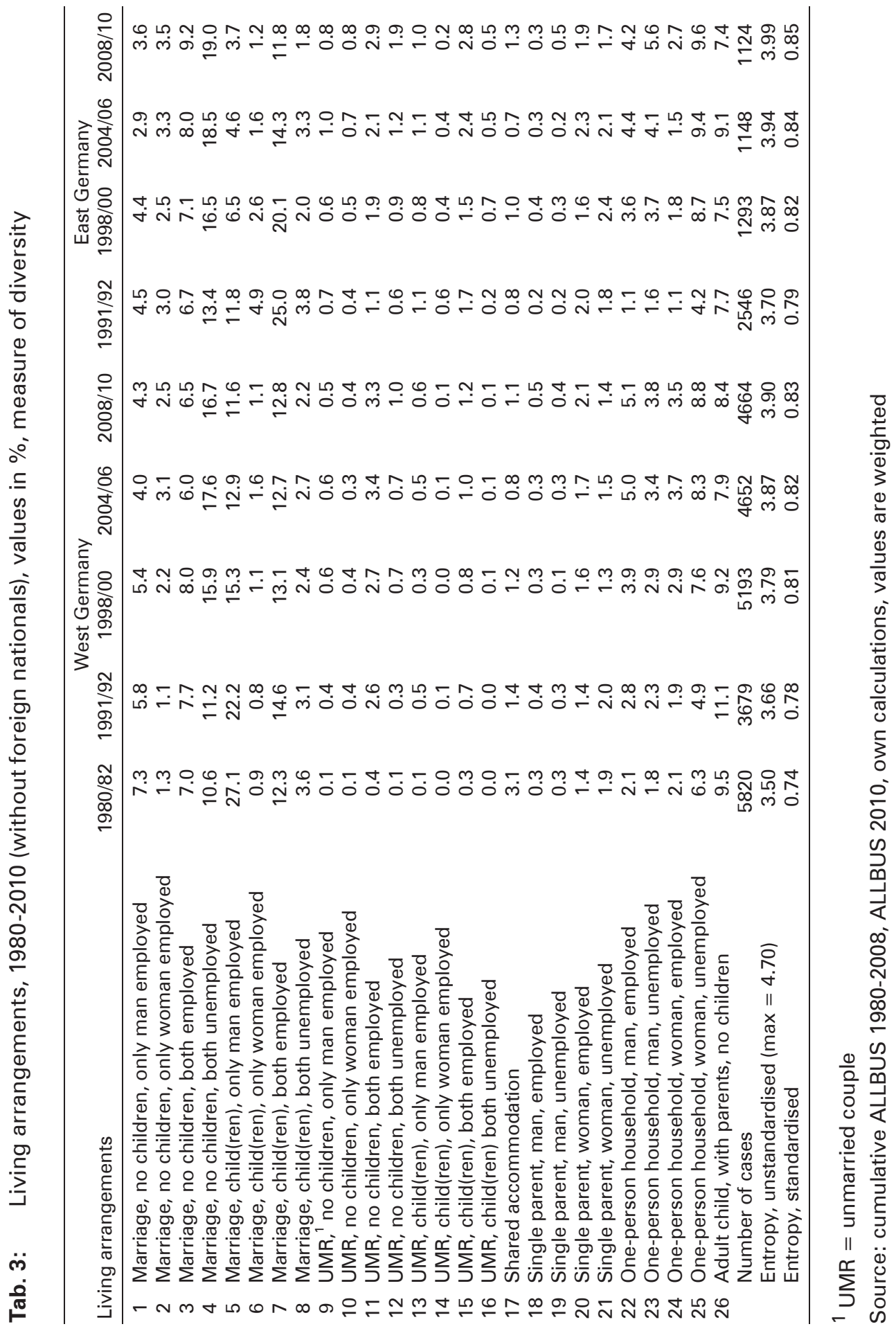


living with children and only 68 percent of these were married in 2008/10. The percentage of - mostly female - single parents has remained at roughly 4 percent in both East and West Germany.

It is noteworthy that not every living arrangement is preferred by the same age group. For example, the median age of married living arrangements - especially marriage without children - is significantly higher than for unmarried relationships. Especially UMRs without children are led by young people whereas most childless married couples with a median age of 60 are presumably pensioners whose children have moved out of the household. Other living arrangements, especially oneperson households, have a very wide age span: both young people and the elderly - presumably mostly widowed women - live in one-person households.

A cohort analysis conducted separately for East and West Germany for the years 1919-21, 1929-31, 1939-41, 1949-51, 1959-61, 1969-71, and 1979-81 reveals that entropy varies for different ages, although the development is similar for the different cohorts (Fig. 1): entropy is lowest at an age of 20; most respondents still live with their parents. At 30, entropy rises sharply, then decreases slightly, and increases again at ages 50 and 60 . At a high age, between 70 and 80, entropy is lower again. Often the level of entropy of younger cohorts is higher than that of older cohorts. However, as this trend does not apply to all age groups, it cannot be concluded that diversity in general increases among subsequent cohorts.

The bimodal entropy that the analysis of different cohorts shows is of particular interest, since the maximum values of diversity are connected to each other. Most people start their own household between the ages of 20 and 30 . This new household can be a shared accommodation, a one-person household or a household with a partner, but also a household with children. The move from the parental home can lead to a change of the parents' living arrangement to a childless household. It is plausible that the diversity of living arrangements is greatest at these two points of life.

A distinctive pattern can be observed for the East Germany: The cohort of people born around 1960 shows the lowest entropy at an age of 30. It only increases at ages 40 and 50. This remarkably low diversity of living arrangements at an age that is usually characterised by many changes, new living arrangements and thus a greater diversity can be attributed to a period effect. At the time of the German reunification this cohort had apparently internalised the traditional GDR model of early marriage to such an extent that nearly half of them was leading the living arrangement "marriage, children, both employed" and new living arrangements were rather an exception. The low willingness to change the living arrangement can also be seen in the decline of divorce rates of East German citizens during the German reunification (Statistisches Bundesamt 2011: 31).

Other cohorts do not present this reunification effect, since they were either at an age when entropy is low anyway (such as the cohorts of 1970 or 1920) or at an age when a change in the living arrangement cannot be described as voluntary, such as the moving out of the last child or the death of the partner (cohort of 1930). 
Fig. 1: Diversity of living arrangements in West/East Germany, cohorts 1919-21 to $1979-81$

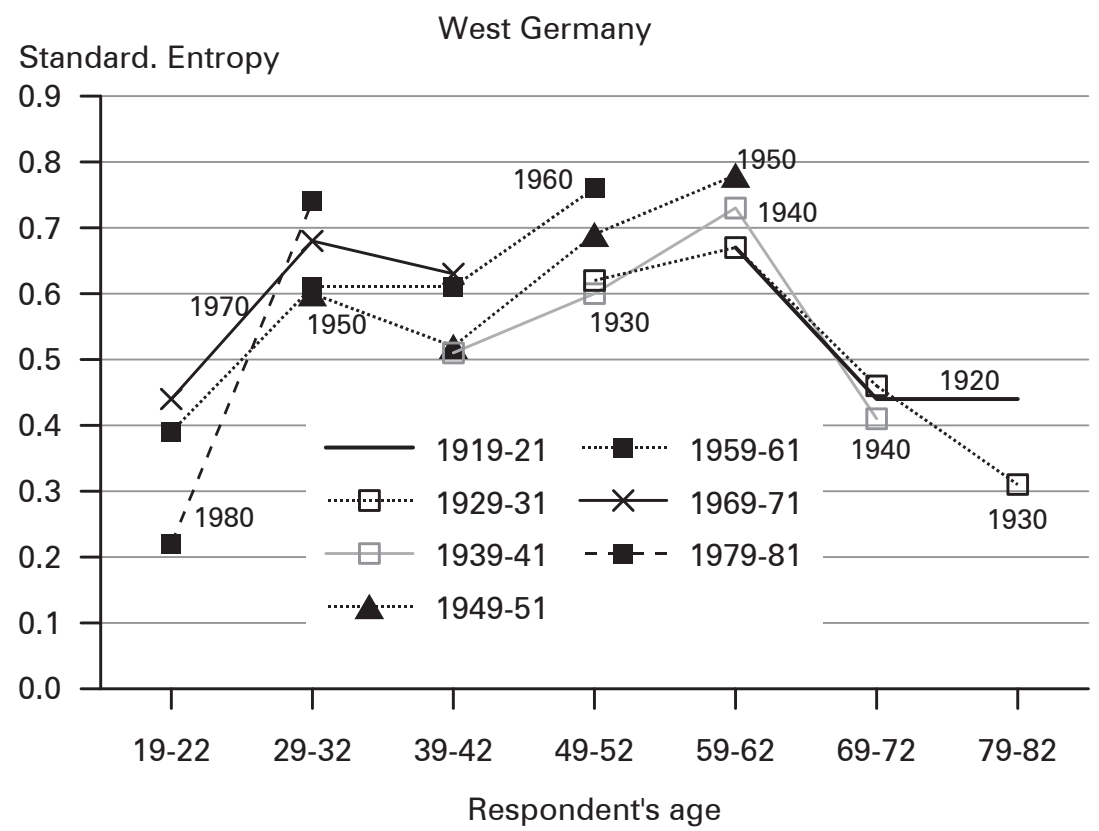

Standard. Entropy

East Germany

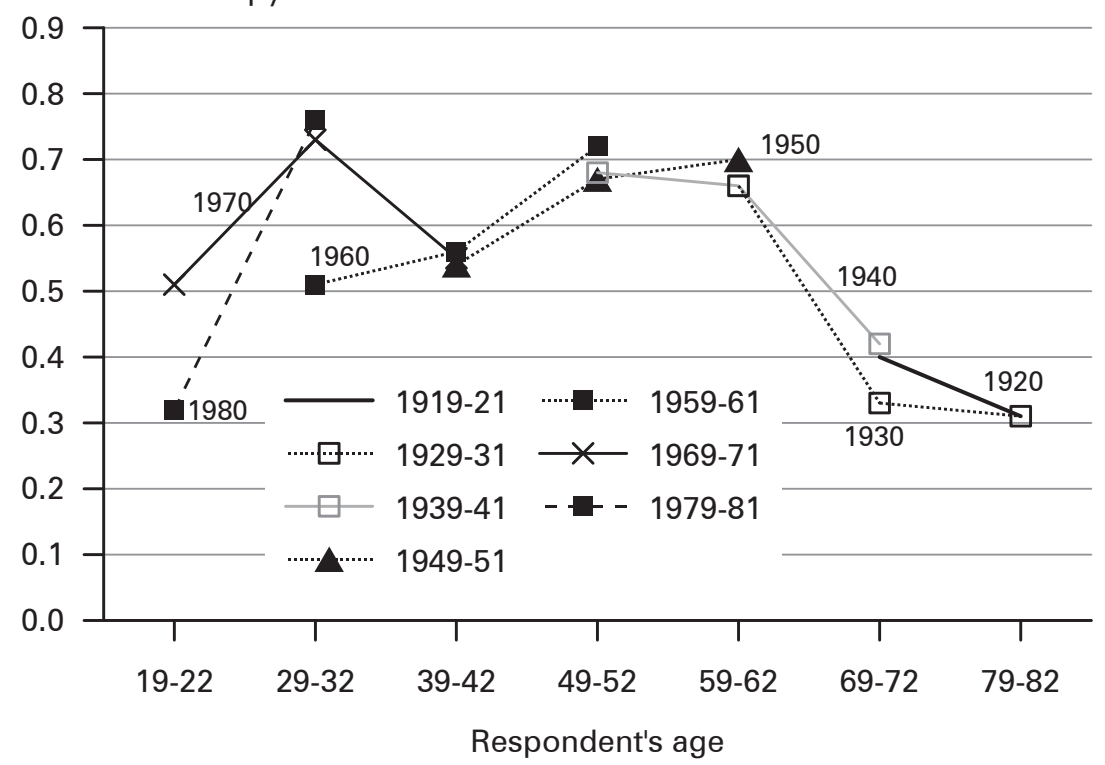

Source: cumulative ALLBUS 1980-2008, ALLBUS 2010, own calculations. The years used are 1980 (only West Germany), 1991, 2000, and 2010. The number of cases from the 1919-21 cohort was too low in 2010. 


\section{$5 \quad$ Summary and discussion}

The aim of this paper was to determine the degree of pluralisation of living arrangements in East and West Germany and to identify possible trends. The pluralisation was analysed applying two methods. First, using the microcensus from 1972, 1996, 2000, and 2007, living arrangements were distinguished on a household-leve/ according to marital status and the number of generations living in a household. Second, using the ALLBUS data from 1980/82 to 2008/10, a classification of living arrangements on an individual leve/ was employed that additionally accounts for the employment status of men and women. It needs to be noted that when shifting from the household level to the individual level the percentage of one-person households decreases while multi-person households gain in importance. The key results were:

On a household level, the diversity of living arrangements in West Germany slightly increased between the 1970s and the 1990s, but has barely changed since then. In the course of this development, the dominant living arrangement of married couples with children was superseded by another living arrangement - one-person households. These make up now nearly 40 percent of all households in West Germany. However, when examining the living arrangements with and without children separately, a different picture emerges. Although the diversity of one-generation households has hardly increased since the 1990s, the familial sector, i.e. households with children, has become more diverse between 2000 and 2007. This development is also due to the fact that the number of marriages with children has decreased. Simultaneously, the proportion of unmarried relationships and single parents has increased.

The diversity of living arrangements in East Germany has even slightly decreased since the middle of the 1990s. However, different developments can be observed here for living arrangements with and without children as well. Whereas the proportion of married couples without children among one-generation households has declined and the proportion of one-person households has increased, which results in a nearly unchanged level of diversity, two-generation households - similar to West Germany - have become more diverse. This is caused by fewer married couples with children and an increase of single parents and unmarried relationships with children. Married couples with children made up only 17 percent of all households in East Germany in 2007, while at the same time they made up 22 percent in West Germany.

The analysis on an individual level - 26 different living arrangements are distinguished - shows a slow but continuous trend of diversification in both East and West Germany. Noteworthy is the decline of partnerships and marriages (with and without children), in which the man is the sole breadwinner. Especially the proportion of childless marriages, in which both man and woman are not employed, has increased; that is mostly marriages of pensioners. The proportions of unmarried relationships and marriages in which both partners are employed have increased, and so have living arrangements in which only the woman is employed. Fewer people live with their children, which is mainly due to a decline of marriages with children in which the man is the sole breadwinner. This decline is not compensated by an 
increase in other living arrangements with children. As the classification of living arrangements on an individual level is very detailed, the percentage of people living in a particular arrangement is often small. There are only three arrangements in which more than 10 percent of the respondents live: childless marriages, in which both partners are not employed, marriages with children and a male breadwinner (only in West Germany), and marriages with children with both partners being employed. One-person households of unemployed women are just below the 10 percent-level as well as childless marriages with both partners being employed (only in East Germany). All other living arrangements are still relatively uncommon, even though their proportions have increased considerably during the last decades.

Cohort analyses further show that the heterogeneity of living arrangements is very similar for certain age groups and cohorts in both parts of the country. Notable is a bipolar distribution with an especially high entropy for 30- and 60-year-olds. This comparatively high heterogeneity is caused by changes in the living arrangement that occur frequently in these age groups: the shift to cohabitation, to a oneperson household, or to marriage for the younger age group, and the moving out of children and thus a shift to an "empty nest" for the older age group. Neither in East nor in West Germany is the level of entropy of subsequent cohorts continuously rising across all age groups. Thus, a trend for a rising diversity in future cannot definitely be expected. East Germany has a distinctive feature: only the cohort of the1960s displays a reunification effect. At an age, which usually displays the highest entropy, the diversification of living arrangements was very low for this cohort. Most of the people in this group were already married and had children, new living arrangements barely existed.

The results demonstrate that a decreasing number of people is living in arrangements in which children are socialised. In contrast, relationships without children and one-person households have increased. This does not imply that individuals always "freely" choose a living arrangement. Family formation may not occur because an adequate partner is missing. Individuals are sometimes also not able to freely choose their living arrangement - as some interpretations of the theory of individualisation and post-materialism suggest - because a change in the living arrangement often occurs due to other members leaving the household (moving out of the parental home, separation, death) or changing (or having to change) their employment status.

The results on the pluralisation of living arrangements are very diverse, since they depend on the selected classification of living arrangements. They can further differ depending on whether the household level or the individual level is analysed. The definition of living arrangements in this paper is based on the household, whereby relationships outside of the household (such as "living apart together", which makes up approximately 6 percent of all living arrangements [see Schneider) Ruckdesche/ 2003: 249], or children not living with one of their parents) are neglected. This is likely to result in an underestimation of the level of diversity. Nevertheless, the definition of living arrangements on the household level is justified, since the household as an economic unit constitutes a clear framework with a certain 
dependence of each household member on one another, allowing for an unambiguous classification of a living arrangement.

Another potential problem when interpreting the pluralisation of living arrangements is the fact that the statistical measures of diversity do not indicate the relative proportion of a particular living arrangement. Thus, the diversity index may remain constant, although the relative diffusion of particular living arrangements has shifted. On the one hand, further conceptual and methodological research is necessary. On the other hand, the results of this paper add to the pluralisation debate and render it more precisely. Earlier research results of Wagner et al. (2001) indicating that the diversity of living arrangements tends to increase over time are largely confirmed. However, a distinction between one- and two-generation households is necessary in order to be able to identify how changes within the familial sector affect the macro level.

Despite some inconsistent empirical findings regarding the pluralisation of living arrangements, it can be stated that unconventional living arrangements have been continuously spreading until today and that both theories of social differentiation and of the deinstitutionalisation of marriage are justified. Although marriage with a male breadwinner has lost its importance, there is no significant increase in living arrangements, in which either both partners are employed or the woman is the sole breadwinner. Therefore, changes of female educational and employment opportunities have influenced the inclination to marry and the formation of families, but have not led to more people living in a partnership or marriage with an "unconventional" distribution of labour.

\section{References}

Amato, Paul R. et al. 2007: Alone Together. How Marriage in America Is Changing. Cambridge/London: Harvard University Press.

Beck, Ulrich 1983: Jenseits von Klasse und Stand? Soziale Ungleichheit, gesellschaftliche Individualisierungsprozesse und die Entstehung neuer sozialer Formationen und Identitäten. In: Kreckel, Reinhard (Ed.): Soziale Ungleichheiten. Göttingen: Schwartz: 35-74.

Brüderl, Josef 2004: Die Pluralisierung partnerschaftlicher Lebensformen in Westdeutschland und Europa. In: Aus Politik und Zeitgeschichte 19: 3-10.

Brüderl, Josef; Klein, Thomas 2003: Die Pluralisierung partnerschaftlicher Lebensformen in Westdeutschland, 1960-2000. In: Bien, Walter; Marbach, Jan H. (Eds.): Partnerschaft und Familiengründung. Ergebnisse der dritten Welle des Familien-Survey. Opladen: Leske+Budrich: 189-217.

Coulter, Philip B. 1989: Measuring Inequality: A Methodological Handbook. Boulder: Westview Press.

Crouch, Colin 2004: Social Change in Western Europe. Oxford: Oxford University Press.

Diewald, Martin; Wehner, Sigrid 1996: Verbreitung und Wechsel von Lebensformen im jüngeren Erwachsenenalter - Der Zeitraum von 1984 bis 1993. In: Zapf, Wolfgang; Schupp, Jürgen; Habich, Roland (Eds.): Lebenslagen im Wandel: Sozialberichterstattung im Längsschnitt. Frankfurt/New York: Campus: 125-146. 
Dorbritz, Jürgen 2004: Demographisches Wissen, Einstellungen zum demographischen Wandel und Ursachen des Geburtenrückgangs. In: Zeitschrift für Bevölkerungswissenschaft 29,3-4: 329-361.

Dorbritz, Jürgen 2010: Kinderzahlen und Lebensformen im West-Ost-Vergleich - Ergebnisse des Mikrozensus 2008. In: Bevölkerungsforschung Aktuell 31: 11-16.

Engstler, Heribert 1998: Die Familie im Spiegel der amtlichen Statistik. Bundesministerium für Familie, Senioren, Frauen und Jugend. Brühl: Chudeck.

Engstler, Heribert; Menning, Sonja 2003: Die Familie im Spiegel der amtlichen Statistik. Lebensformen, Familienstrukturen, wirtschaftliche Situation der Familien und familiendemographische Entwicklung in Deutschland. Erstellt im Auftrag des Bundesministeriums für Familie, Senioren, Frauen und Jugend in Zusammenarbeit mit dem Statistischen Bundesamt. Berlin.

Engstler, Heribert; Tesch-Römer, Clemens 2010: Lebensformen und Partnerschaft. In: Motel-Klingebiel, Andreas; Wurm, Susanne; Tesch-Römer, Clemens (Eds.): Altern im Wandel. Befunde des Deutschen Alterssurveys (DEAS). Stuttgart: Kohlhammer: 163187.

Esping-Andersen, Gøsta 2009: The Incomplete Revolution. Adapting to Women's New Roles. Cambridge: polity.

Franzmann, Gabriele; Wagner, Michael 1999: Heterogenitätsindizes zur Messung der Pluralität von Lebensformen und ihre Berechnung in SPSS. In: ZA-Information 44: 75-95.

GESIS 2010: Allgemeine Informationen zum ALLBUS [http://www.gesis.org/dienstleistungen/daten/umfragedaten/allbus/allgemeine-informationen/, 25.01.2011].

Heidenreich, Hans-Joachim; Nöthen, Manuela 2002: Der Wandel der Lebensformen im Spiegel des Mikrozensus. In: Wirtschaft und Statistik 1: 26-38.

Hill, Paul B.; Kopp, Johannes 1999: Nichteheliche Lebensgemeinschaften - theoretische Aspekte zur Wahl von Lebensformen. In: Klein, Thomas; Lauterbach, Wolfgang (Eds.): Nichteheliche Lebensgemeinschaften. Analysen zum Wandel partnerschaftlicher Lebensformen. Opladen: Leske+Budrich: 11-35.

Holzem, Andreas; Weber, Ines 2008: Ehe - Familie - Verwandtschaft. Vergesellschaftung in Religion und sozialer Lebenswelt. Paderborn: Schöningh.

Höhn, Charlotte; Dorbritz, Jürgen 1995: Zwischen Individualisierung und Institutionalisierung - Familiendemographische Trends im vereinten Deutschland. In: Nauck, Bernhard; Onnen-Isemann, Corinna (Eds.): Familie im Brennpunkt von Wissenschaft und Forschung. Neuwied: Luchterhand: 149-174.

Huinink, Johannes; Konietzka, Dirk 2003: Lebensformen und Familiengründung. Nichteheliche Elternschaft in Ost- und Westdeutschland in den 1990er Jahren. In: Bien, Walter; Marbach, Jan H. (Eds.): Partnerschaften und Familiengründung. Ergebnisse der dritten Welle des Familien-Survey. Opladen: Leske+Budrich: 65-93.

Huinink, Johannes; Wagner, Michae/ 1998: Individualisierung und die Pluralisierung von Lebensformen. In: Friedrichs, Jürgen (Ed.): Die Individualisierungs-These. Opladen: Leske+Budrich: 85-106.

Kaufmann, Franz-Xaver 1988: Familie und Modernität. In: Lüscher, Kurt; Schultheis, Franz; Wehrspaun, Michael (Eds.): Die „postmoderne“ Familie: familiale Strategien und Familienpolitik in einer Übergangszeit. Konstanz: Universitätsverlag: 391-416.

Kaufmann, Franz-Xaver 1995: Zukunft der Familie im vereinten Deutschland. Gesellschaftliche und politische Bedingungen. München: Beck. 
Klein, Thomas 1999: Pluralisierung versus Umstrukturierung am Beispiel partnerschaftlicher Lebensformen. In: Kölner Zeitschrift für Soziologie und Sozialpsychologie 51,3: 469-490.

Klein, Thomas 2005: Sozialstrukturanalyse. Eine Einführung. Reinbek: Rowohlt.

Lengerer, Andrea 2011: Partnerlosigkeit in Deutschland. Wiesbaden: VS Verlag für Sozialwissenschaften.

Lengerer, Andrea; Hanßen, Andrea; Bohr, Jeanette 2007: Familiensoziologische Analysepotenziale des Mikrozensus. In: Zeitschrift für Familienforschung 19: 186-209.

Lieberson, Stanley 1969: Measuring Population Diversity. In: American Sociological Review 34: 850-862.

Lüscher, Kurt 1985: Moderne familiale Lebensformen als Herausforderung der Soziologie. In: Lutz, Burkart (Ed.): Soziologie und gesellschaftliche Entwicklung. Verhandlungen des 22. Deutschen Soziologentages in Dortmund 1984. Frankfurt/New York: Campus: 110-127.

Marbach, Jan H. 2003: Familiale Lebensformen im Wandel. In: Bien, Walter; Marbach, Jan $H$. (Eds.): Partnerschaften und Familiengründung. Ergebnisse der dritten Welle des Familien-Survey. Opladen: Leske+Budrich: 141-187.

Meyer, Thomas 1992: Modernisierung der Privatheit. Differenzierungs- und Individualisierungsprozesse des familialen Zusammenlebens. Opladen: Westdeutscher Verlag.

Meyer, Thomas 1993: Der Monopolverlust der Familie. Vom Teilsystem Familie zum Teilsystem privater Lebensformen. In: Kölner Zeitschrift für Soziologie und Sozialpsychologie 45: 23-40.

Meyer, Sibylle; Schulze, Eva 1983: Nichteheliche Lebensgemeinschaften - Alternativen zur Ehe? Eine internationale Datenübersicht. In: Kölner Zeitschrift für Soziologie und Sozialpsychologie 35: 735-754.

Nave-Herz, Rosemarie 1999: Die nichteheliche Lebensgemeinschaft als Beispiel gesellschaftlicher Differenzierung. In: Klein, Thomas; Lauterbach, Wolfgang (Eds.): Nichteheliche Lebensgemeinschaften. Analysen zum Wandel partnerschaftlicher Lebensformen. Opladen: Leske+Budrich: 37-59.

Niemeyer, Frank; Voit, Hermann 1995: Lebensformen der Bevölkerung 1993. Wirtschaft und Statistik 6: 437-445.

Nöthen, Manuela 2005: Von der "traditionellen Familie“ zu den „neuen Lebensformen”. In: Wirtschaft und Statistik 1: 25-40.

Peet, Robert K. 1974: The Measurement of Species Diversity. In: Annuals Review of Ecology and Systematics 5: 285-307.

Peuckert, Rüdiger 2008: Familienformen im sozialen Wandel. Wiesbaden: VS- Verlag für Sozialwissenschaften.

Schimank, Uwe 2000: Theorien gesellschaftlicher Differenzierung, 2. Auflage. Opladen: Leske+Budrich.

Schneider, Norbert F.; Ruckdeschel, Kerstin 2003: Partnerschaften mit zwei Haushalten: Eine moderne Lebensform zwischen Partnerschaftsideal und beruflichen Erfordernissen. In: Bien, Walter; Marbach, Jan H. (Eds.): Partnerschaft und Familiengründung. Ergebnisse der dritten Welle des Familien-Survey. Opladen: Leske+Budrich: 245-258.

Statistisches Bundesamt (Eds.) 2010: Datenhandbuch zum Mikrozensus Scientific Use File 2007. Bonn.

Statistisches Bundesamt (Eds.) 2011: Datenreport 2011. Ein Sozialbericht für die Bundesrepublik Deutschland. Bonn: Bundeszentrale für politische Bildung. 
Strohmeier, Klaus Peter 1993: Pluralisierung und Polarisierung der Lebensformen in Deutschland. In: Aus Politik und Zeitgeschichte 17: 11-22.

Tyrell, Hartmann 1979: Familie und gesellschaftliche Differenzierung. In: Pross, Helge (Ed.): Familie wohin? Leistungen, Leistungsdefizite und Leistungswandlungen der Familien in hochindustrialisierten Gesellschaften. Reinbek: Rowohlt: 13-77.

Tyrell, Hartmann 1988: Ehe und Familie - Institutionalisierung und Deinstitutionalisierung. In: Lüscher, Kurt; Schultheis, Franz; Wehrspaun, Michael (Eds.): Die postmoderne Familie. Konstanz: Universitätsverlag: 145-156.

Wagner, Michae/ 2008: Entwicklung und Vielfalt der Lebensformen. In: Schneider, Norbert F. (Ed.): Lehrbuch Moderne Familiensoziologie. Opladen/Farmington Hills: Barbara Budrich: 99-120.

Wagner, Michael; Franzmann, Gabriele 2000: Die Pluralisierung der Lebensformen. In: Zeitschrift für Bevölkerungswissenschaft 25: 151-173.

Wagner, Michael; Franzmann, Gabriele; Stauder, Johannes 2001: Neue Befunde zur Pluralität der Lebensformen. In: Zeitschrift für Familienforschung 13: 52-73.

Zapf, Wolfgang et al. 1987: Individualisierung und Sicherheit. Untersuchungen zur Lebensqualität in der Bundesrepublik Deutschland. München: Beck.

Translated from the original text by the Federal Institute for Population Research, for information only. The reviewed and authors' authorised original article in German is available under the title "Die Pluralisierung der Lebensformen - Ein fortlaufender Trend?", DOI 10.12765/CPoS-2014-03de or URN urn:nbn:de:bib-cpos-2014-03de7, at http://www.comparativepopulationstudies.de.

Prof. Dr. Michael Wagner ( $\bowtie)$. University of Cologne, Institute for Sociology and Social Psychology. Köln, Germany. E-Mail: mwagner@wiso.uni-koeln.de URL: http://www.iss-wiso.uni-koeln.de/wagner.html

Isabel Valdés Cifuentes. University of Hamburg, School of Economics and Social Sciences, Department of Socio-Economics. Hamburg, Germany.

E-Mail: Isabel.ValdesCifuentes@wiso.uni-hamburg.de

URL: http://www.wiso.uni-hamburg.de/professuren/sozialer-wandel/team/

wissenschaftliche-mitarbeiterinnen/isabel-valdes-cifuentes/ 


\section{Appendix}

Tab. A1: Individual-level diversity of living arrangements (West Germany) Comparison of ALLBUS and the micro census

\begin{tabular}{lcc}
\hline Living arrangements & ALLBUS 2008 & Microcensus 2007 \\
\hline Marriage without children & 34.4 & 33.1 \\
UMR ${ }^{1}$ without children & 5.1 & 5.5 \\
One-person household & 22.2 & 27.0 \\
Marriage with children & 31.1 & 28.5 \\
UMR with children & 2.0 & 1.9 \\
Single parent & 5.2 & 4.0 \\
Total & 100 & 100 \\
Entropy (max. 2.59) & 2.09 & 2.08 \\
Entropy. standardised & 0.81 & 0.80 \\
\hline
\end{tabular}

${ }^{1}$ UMR = unmarried couple

Source: own calculations based on the ALLBUS 1980-2008 and the micro census 2007 


\section{Comparative Population Studies}

WWW.comparativepopulationstudies.de

ISSN: 1869-8980 (Print) - 1869-8999 (Internet)

Published by / Herausgegeben von

Prof. Dr. Norbert F. Schneider

Federal Institute for Population Research

D-65180 Wiesbaden / Germany

Managing Editor /

Verantwortlicher Redakteur

Frank Swiaczny

Assistant Managing Editor /

Stellvertretende Redakteurin

Katrin Schiefer

Language \& Copy Editor (English) /

Lektorat \& Übersetzungen (englisch)

Amelie Franke

\section{Copy Editor (German) /}

Lektorat (deutsch)

Dr. Evelyn Grünheid

\section{Layout / Satz}

Beatriz Feiler-Fuchs

E-mail:cpos@bib.bund.de

\author{
Scientific Advisory Board / \\ Wissenschaftlicher Beirat \\ Paul Gans (Mannheim) \\ Johannes Huinink (Bremen) \\ Michaela Kreyenfeld (Berlin) \\ Marc Luy (Wien) \\ Clara H. Mulder (Groningen) \\ Notburga Ott (Bochum) \\ Peter Preisendörfer (Mainz) \\ Zsolt Spéder (Budapest)
}

\section{Board of Reviewers / Gutachterbeirat} Martin Abraham (Erlangen) Laura Bernardi (Lausanne) Hansjörg Bucher (Bonn) Claudia Diehl (Konstanz) Andreas Diekmann (Zürich) Gabriele Doblhammer-Reiter (Rostock) E.-Jürgen Flöthmann (Bielefeld) Alexia Fürnkranz-Prskawetz (Wien) Beat Fux (Zürich) Joshua Goldstein (Rostock) Karsten Hank (Köln) Sonja Haug (Regensburg) Aart C. Liefbroer (Den Haag) Kurt Lüscher (Konstanz) Dimiter Philipov (Wien) Tomáš Sobotka (Wien) Heike Trappe (Rostock) 